\title{
Nociceptors: the sensors of the pain pathway
}

\author{
Adrienne E. Dubin ${ }^{1}$ and Ardem Patapoutian ${ }^{1,2}$
}

\author{
1Department of Cell Biology, The Scripps Research Institute, La Jolla, California, USA. \\ ${ }^{2}$ Genomics Institute of the Novartis Research Foundation, San Diego, California, USA.
}

\begin{abstract}
Specialized peripheral sensory neurons known as nociceptors alert us to potentially damaging stimuli at the skin by detecting extremes in temperature and pressure and injury-related chemicals, and transducing these stimuli into long-ranging electrical signals that are relayed to higher brain centers. The activation of functionally distinct cutaneous nociceptor populations and the processing of information they convey provide a rich diversity of pain qualities. Current work in this field is providing researchers with a more thorough understanding of nociceptor cell biology at molecular and systems levels and insight that will allow the targeted design of novel pain therapeutics.
\end{abstract}

\section{Introduction}

Pain, as a submodality of somatic sensation, has been defined as a "complex constellation of unpleasant sensory, emotional and cognitive experiences provoked by real or perceived tissue damage and manifested by certain autonomic, psychological, and behavioral reactions" (1). The benefit of these unpleasant sensations, however, is underscored by extreme cases: patients lacking the ability to perceive pain due to hereditary neuropathies often maintain unrealized infections, self mutilate, and have curtailed life spans (2). Normally, nociception (see Glossary, Sidebar 1) and the perception of pain are evoked only at pressures and temperatures extreme enough to potentially injure tissues and by toxic molecules and inflammatory mediators. These high threshold physical and noxious chemical stimuli are detected by specialized peripheral sensory neurons (nociceptors). This is in contrast to the high sensitivity of visual, auditory, olfactory, taste, and somatosensory organs to their adequate stimuli. Pain is described as having different qualities and temporal features depending on the modality and locality of the stimulus, respectively: first pain is described as lancinating, stabbing, or pricking; second pain is more pervasive and includes burning, throbbing, cramping, and aching and recruits sustained affective components with descriptors such as "sickening" (3). The intensity of these global reactions underscores the importance of avoiding damaging situations for survival and maintaining homeostasis. As opposed to the relatively more objective nature of other senses, pain is highly individual and subjective $(4,5)$ and the translation of nociception into pain perception can be curtailed by stress or exacerbated by anticipation (6).

Here, we review the nociceptive aspect of pain perception, focusing on nociceptors innervating the skin and subserving exteroception of noxious stimuli. Discussion of the similarities and differences among cutaneous, visceral, muscle, and joint nociception can be found elsewhere (7-9). We provide an overview of how noxious stimuli are detected, encoded, and conveyed to the CNS. Since recent reviews have described in detail the molecules involved in detecting noxious stimuli (10-13) and contributing to protective mechanisms mediating enhanced pain at the site of injury (14), we take an integrative approach that highlights recently discovered cellular transduction/conduction mechanisms in the context of different nociceptor fiber types identified in vivo and ex vivo. We further discuss innovations using genetic and pharmacological tools that begin to address how particular nociceptor populations

Conflict of interest: The authors have declared that no conflict of interest exists. Citation for this article: J Clin Invest. 2010;120(11):3760-3772. doi:10.1172/JCI42843. contribute to the perception of specific pain qualities. Since maladaptive changes in normal physiological mechanisms underlie a variety of pathologies leading to chronic pain, a thorough understanding of nociception is required to identify the interventions most likely to provide therapeutic benefit.

\section{Anatomy and physiology of cutaneous nociception}

Significant insights into the cellular and molecular basis of cutaneous nociception have been realized from studies on conscious humans and surrogate animal models $(15,16)$, although we are far from understanding the cell biology of pain perception. Advances are hampered by the difficulties inherent in studying neuronal processes in humans, cellular changes in nociceptors induced by invasive methods, the inability to record directly from the tiny structures where transduction of noxious stimuli occurs, and the uncertainty in model systems that an animal's behavior is due to its perception of pain $(15,17)$. Although the morphology of sensory nociceptive nerve endings is highly conserved in animals from rodents to humans $(5,9,17-19)$, cutaneous nociceptors are an extremely heterogeneous group of neurons housed in peripheral sensory ganglia located just outside the CNS that transduce external noxious stimuli in the skin, up to meters away from their cell bodies.

Minimally invasive extracellular single unit recordings from nerve fibers in peripheral nerves (microneurography) and skinnerve preparations in mammals (20) and microneurography combined with psychophysical measurements in human subjects $(15,16,21)$ have revealed the existence of distinct classes of nociceptor activated by noxious stimuli. Adequate stimuli include temperature extremes $\left(>\sim 40^{\circ} \mathrm{C}-45^{\circ} \mathrm{C}\right.$ or $\left.<\sim 15^{\circ} \mathrm{C}\right)$, intense pressure, and chemicals signaling potential or actual tissue damage. Nociceptors are generally electrically silent (12) and transmit allor-none action potentials only when stimulated. However, nociceptor activity does not per se lead to the perception of pain. The latter requires peripheral information to reach higher centers and normally depends on the frequency of action potentials in primary afferents, temporal summation of pre- and postsynaptic signals, and central influences (7).

The speed of transmission is directly correlated to the diameter of axons of sensory neurons and whether or not they are myelinated. Most nociceptors have small diameter unmyelinated axons (C-fibers) (12) bundled in fascicles surrounded by Schwann cells and support conduction velocities of $0.4-1.4 \mathrm{~m} / \mathrm{s}$ (22) (Figure 1). Initial fast-onset pain is mediated by A-fiber nociceptors whose axons are myelinated and support conduction velocities of approximately $5-30 \mathrm{~m} / \mathrm{s}$ (most in the slower A range) (22). Nociceptive fibers have been 


\section{Sidebar 1}

\section{Glossary}

Action potential, actively propagating electric signal along neuronal processes that enables communication to postsynaptic neurons in the pain pathway

Allodynia, pain evoked by a normally innocuous stimulus

Antidromic, transmission of action potentials against the peripheral to central direction

Axon reflex, the invasion of orthodromic (afferent) action potentials into other terminal branches of the same axon innervating the skin (antidromic, efferent) can cause the release of proinflammatory substances (e.g., peptides) from those peripheral terminals to have a local effect on nearby terminals and nonneuronal components including the vasculature

Central sensitization, changes in synaptic efficacy between sensory neurons and central (spinal dorsal horn) neurons that increase the perception of pain, especially in regions adjacent to the primary site of injury

Fatigue, a decrement in response to repeated stimuli applied to the receptive field of sensory cell

Hyperalgesia, an increase in the perception of pain elicited by a noxious stimulus; Hyperalgesic, a treatment that increases the sensitivity to noxious stimuli; Primary hyperalgesia, increased pain perception in area of injury or exposure to noxious stimulus; Secondary hyperalgesia, increased pain perception in the region surrounding the area exposed to a noxious stimulus. Can be associated with a decrease in threshold and/or increase in suprathreshold response

Inflammatory pain, pain associated with tissue injury and inflammation characterized by reduced threshold and increased responsiveness

Low threshold A-fibers, sensory neurons that innervate nonneuronal Merkel cells (A $\beta$-LTM SA I), Meissner corpuscle (A $\beta$-LTM FA I), Ruffini corpuscle (sensitive to stretch; A $\beta$-LTM SA II), pacinian corpuscle (vibration; A $\beta$-LTM FAII), and hairs (hair movement; G1 hair (Aß-LTM FA1), and Down (D-) hair (Aס-LTM))

Mechanical stimulation, punctate mechanical stimulation: measuring reflex responses to constant force applied by calibrated filaments (often by Von Frey hairs). Pinch: Randall-Selitto increases pressure to the paw or tail via a clamp system. $1 \mathrm{bar}=14.51 \mathrm{psi}=0.987 ; \mathrm{atm}=750 \mathrm{~mm} \mathrm{Hg}($ Torr $)=100,000 \mathrm{~Pa}\left(\mathrm{~N} / \mathrm{m}^{2}\right)=\sim 10 \mathrm{~g} / \mathrm{mm}^{2}$. Ambient pressure on the skin at sea level is $1 \mathrm{bar}\left(\sim 10 \mathrm{~g} / \mathrm{mm}^{2}\right)$

Myelinated neurons, neurons whose axons are wrapped within a membrane-rich myelin sheath that enables the action potential to jump between axonal nodes of Ranvier (myelin-free areas) to increase the speed of its propagation (conduction velocity)

Neurogenic inflammation, a general term used to describe the effects of the local release of inflammatory mediators such as substance P and CGRP from afferent nerve terminals

Nociception, the neural process of encoding and processing noxious stimuli

Nociceptor, a peripherally localized neuron preferentially sensitive to a noxious stimulus or to a stimulus that would become noxious if prolonged; capable of encoding stimulus intensities within the noxious range; may have a wide dynamic range of thresholds from innocuous to noxious range but stimulus-response relationship peaks in the noxious range; these also include those that are not activated immediately but become responsive to heat and mechanical stimulation upon prolonged stimulation

Nocifensive behaviors, "signs" of pain including "pseudoaffective reflexes" (e.g., withdrawal, jumping, contractures) and conditioned motor responses (e.g., escape, avoidance, aggressiveness). Immobility (a behavior that could allow the animal to preserve a painless posture) is often not scored (15)

Noxious stimuli, damaging or potentially damaging stimuli including extremes of temperature, mechanical stimulation, and allogens that provoke an avoidance response

Nocisensor, a molecule that detects noxious stimuli and transduces the stimulus to a cellular response

Plasticity, a dynamic modulation of signaling

Receptive field (cutaneous), area of skin on which stimulation leads to response of a particular sensory neuron

Receptor potential, the change in membrane potential that occurs in the peripheral terminal due to transduction of a stimulus into ion flux, either through direct and/or indirect (through recruitment of second messenger cascades) modulation of ion channel activity

classified (23) on the basis of their conduction velocity and sensitivity and threshold to noxious mechanical $(\mathrm{M})$, heat $(\mathrm{H})$, and cold (C) (Tables 1 and 2) $(9,23)$. Units responding to thermal, mechanical, and chemical stimuli (polymodal) are the most common $\mathrm{C}$-fiber type observed in fiber recordings (C-MH, C-MC, C-MHC) $(7,9,24)$ (Table 1). The expression of differential repertoires of transduction molecules (particularly chemical sensors) confers a rich functional heterogeneity upon this class. The use of electrical stimulation to search for receptive fields, rather than mechani- cal stimulation, identified nociceptors normally insensitive to mechanical and heat stimulation (silent; $\mathrm{C}-\mathrm{M}_{\mathrm{i}} \mathrm{H}_{\mathrm{i}}$ ) that become sensitive to noxious mechanical or temperature only after being sensitized by inflammatory mediators $(25,26)$. C-fibers responsive to noxious heat ( $\mathrm{C}-\mathrm{H} ; \sim 10 \%$ of C-nociceptors) play a major role in heat sensation (see below). A-fiber nociceptors are predominately heat- and or mechanosensitive (A-MH, A-H, A-M) $(19,27)$ (Table 2); however, sensitivity to noxious cold is also observed (27-29). Determining the contribution of each of these fiber types to pain 
A

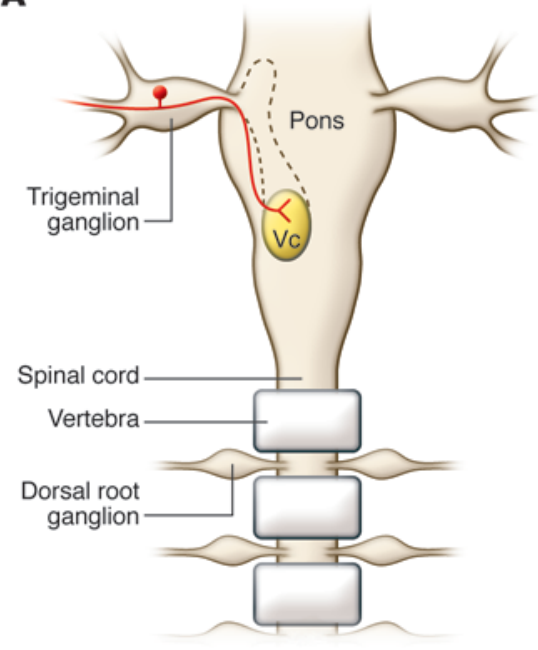

B

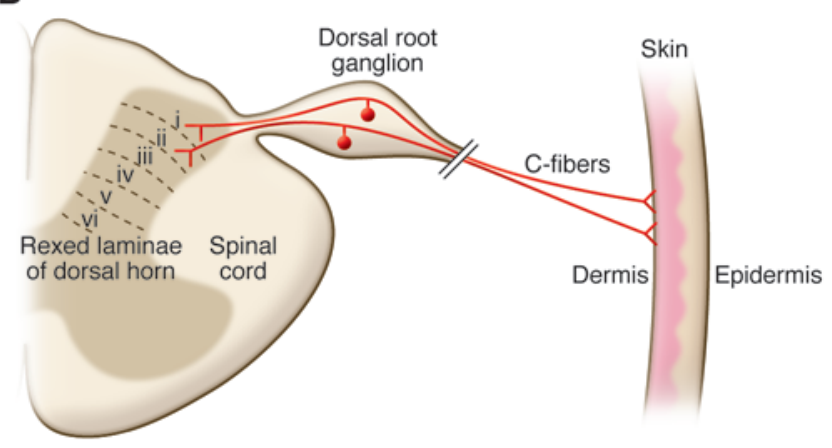

C

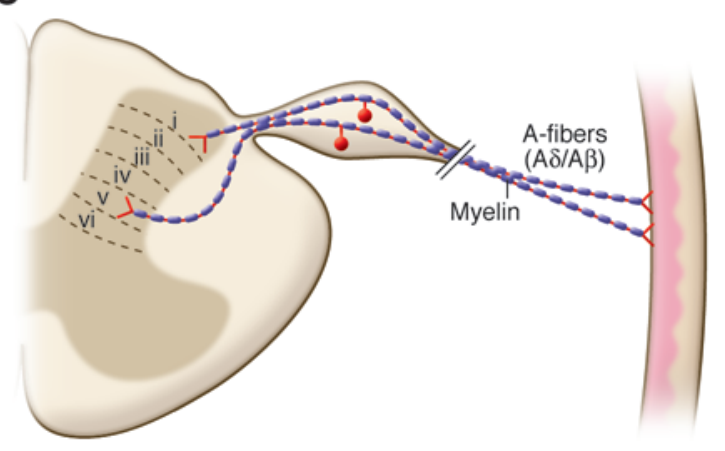

perception requires an understanding of the molecular mechanisms underlying the detection of particular stimulus modalities and nociceptor connectivity in central circuits.

Noxious stimuli are transduced into electrical signals in free "unencapsulated" nerve endings that have branched from the main axon and terminate in the wall of arterioles and surrounding connective tissue, and may innervate distinct regions in the dermis and epidermis $(17,30)$. The endings are ensheathed by Schwann cells except at the end bulb and at mitochondria- and vesicle-rich varicosities (17). A-fibers lose their myelin sheath and the unmyelinated A-fiber branches cluster in separated small spots within a small area, the anatomical substrate for their receptive field (17). C-fiber branches are generally more broadly distributed, precluding precise localization of the stimulus (17). In contrast, special-

\section{Figure 1}

Anatomy of nociceptors. (A) Somatosensory neurons are located in peripheral ganglia (trigeminal and dorsal root ganglia) located alongside the spinal column and medulla. Afferent neurons project centrally to the brainstem $(\mathrm{Vc})$ and dorsal horn of the spinal cord and peripherally to the skin and other organs. Vc, trigeminal brainstem sensory subnucleus caudalis. (B) Most nociceptors are unmyelinated with small diameter axons (C-fibers, red). Their peripheral afferent innervates the skin (dermis and/or epidermis) and central process projects to superficial laminae I and II of the dorsal horn. (C) A-fiber nociceptors are myelinated and usually have conduction velocities in the Ad range (red). A-fiber nociceptors project to superficial laminae I and V.

ized nonneuronal structures conferring high sensitivity to light touch, stretch, vibration, and hair movement are innervated by low threshold A-fibers (11). Nociceptive endings are in the vicinity of keratinocytes, mast cells, and Langerhans cells, indicating the capacity of peripheral sensory endings to monitor the status of the skin (31). Nociceptors, like other primary somatosensory neurons, are pseudounipolar (Figure 1): a single process emanates from the cell body in the dorsal root ganglion (DRG) or trigeminal ganglion (TG) and bifurcates, sending a peripheral axon to innervate the skin and a central axon to synapse on second-order neurons in the dorsal horn of the spinal cord or the trigeminal subnucleus caudalis $(\mathrm{Vc})(13)$, respectively (Figure 1A). In this way, propagating electrical signals between periphery and spinal cord (or brainstem) follow a direct axonal pathway, thus reducing the risk of conduction failure (32). Nociceptors are excitatory neurons and release glutamate as their primary neurotransmitter as well as other components including peptides (e.g., substance P, calcitonin generelated peptide [CGRP], somatostatin) important in both central synaptic signaling and efferent signaling in the skin (13). Invasion of action potentials into the nociceptor soma via the short stem axon (32) can lead to biochemical changes (e.g., phosphorylation and activation of MAPK superfamily of signaling pathways) that ultimately alter gene expression and functional phenotype $(33,34)$. Although it is thought that direct communication between the soma of primary sensory neurons does not occur, vesicle exocytosis is observed in dissociated soma and may influence associated Schwann cells and possibly nearby neurons $(35,36)$. The central axon of DRG neurons enters the spinal cord via the dorsal root and sprouts branches that innervate multiple spinal segments in the rostral and caudal direction as well as the segment associated with the particular DRG and dorsal column nuclei of the caudal medulla (7). They terminate predominantly in laminae I, II, and V of the dorsal horn on relay neurons and local interneurons important for signal modification $(13,37,38)$ (Figure 1, B and C). The relay neurons project to the medulla, mesencephalon, and thalamus, which in turn project to somatosensory and anterior cingulate cortices to drive sensory-discriminative and affective-cognitive aspects of pain, respectively (38). Local inhibitory and excitatory interneurons in the dorsal horn as well as descending inhibitory and facilitatory pathways originating in the brain modulate the transmission of nociceptive signals, thus contributing to the prioritization of pain perception relative to other competing behavioral needs and homeostatic demands (39).

The cell body (soma) has served as an extremely useful model to study molecules and modulatory mechanisms mediating transduction of noxious stimuli, transmission of electrical signals to the CNS, and release of neurotransmitters and neuropeptides 


\section{Table 1}

Major heat and/or mechanosensitive nociceptor C-fiber classes

\begin{tabular}{|c|c|c|c|c|c|}
\hline & \multicolumn{2}{|c|}{ Mechanical sensitivity } & \multicolumn{2}{|c|}{ Mechanical insensitivity } & \multirow[t]{2}{*}{ References } \\
\hline & C-MH & C-M & $\mathrm{C}-\mathrm{H}$ & C- $\mathrm{M}_{\mathrm{i}} \mathrm{H}_{\mathrm{i}}$ ("silent") & \\
\hline Percentage observed & 35-approaching 100 & $10-15$ & $5-10$ & $10-25$ & $25,50,67$ \\
\hline $\mathrm{CV}(\mathrm{m} / \mathrm{s})$ & $\begin{array}{c}0.8-1.0 \text { (human, monkey); } \\
\sim 0.5 \text { (mouse) }\end{array}$ & $\begin{array}{l}0.84 \text { (human); } \\
\sim 0.5 \text { (mouse }\end{array}$ & $\begin{array}{l}0.81 \text { (human); } \\
0.87 \text { (monkey); } \\
0.35 \text { (mouse); slower } \\
\text { than mechanically } \\
\text { sensitive C-fibers) }\end{array}$ & $\begin{array}{l}0.80 \text { (human); } \\
0.82 \text { (monkey); slower } \\
\text { than mechanically } \\
\text { sensitive C-fibers }\end{array}$ & $\begin{array}{c}25,50,55 \\
123,124\end{array}$ \\
\hline $\begin{array}{l}\text { Correlation of } \\
\text { heat response } \\
\text { and PR }\end{array}$ & $\begin{array}{c}\text { Yes/repeated } \\
\text { stimulation sensitizes } \\
\text { (hairy, not glabrous) }\end{array}$ & NA & Unknown & NA & $24,67,106$ \\
\hline Heat threshold & $39^{\circ} \mathrm{C}-51^{\circ} \mathrm{C}$ & NA & $42^{\circ} \mathrm{C}, 48^{\circ} \mathrm{C}(>\mathrm{C}-\mathrm{MH})$ & NA & $\begin{array}{c}50,55,67 \\
123,124\end{array}$ \\
\hline $\begin{array}{l}\text { Correlation of } \\
\text { mechanical response } \\
\text { to punctuate } \\
\text { stimulation and PR }\end{array}$ & $\begin{array}{c}\text { Static: no; } \\
\text { accelerating: yes }\end{array}$ & Accelerating: yes & NA & NA & 24,125 \\
\hline Mechanical threshold & $\begin{array}{l}30 \mathrm{mN} \text { (human); } \\
25 \mathrm{mN} \text { (monkey); } \\
17 \mathrm{mN} \text { (mouse) }\end{array}$ & $\begin{array}{l}30 \mathrm{mN} \text { (human); } \\
18 \mathrm{mN} \text { (mouse) }\end{array}$ & High & High & $\begin{array}{l}25,26 \\
50,55\end{array}$ \\
\hline $\begin{array}{l}\text { Correlation of tonic } \\
\text { pinch response to } \\
\text { tonic pinch and PR }\end{array}$ & $\begin{array}{l}\text { Yes; initial pain; } \\
\text { adapting }\end{array}$ & $\begin{array}{l}\text { Yes; initial pain; } \\
\text { adapting }\end{array}$ & $\begin{array}{l}\text { Yes: slow development } \\
\text { of pain; sensitization; } \\
\text { perhaps indirect }\end{array}$ & $\begin{array}{l}\text { Yes: slow development } \\
\text { of pain; sensitization; } \\
\text { perhaps indirect }\end{array}$ & $9,18,126$ \\
\hline $\begin{array}{l}\text { Electrical stimulation } \\
\text { of axon } \rightarrow \text { flare }\end{array}$ & $\begin{array}{l}\text { No: uninjured skin } \\
\text { Yes: UV-B-treated skin }\end{array}$ & No: uninjured skin & $\begin{array}{l}\text { Yes: restricted to } \\
\text { receptive field }\end{array}$ & Yes & $127-130$ \\
\hline $\begin{array}{l}\text { Known chemical } \\
\text { activators }\end{array}$ & $\begin{array}{c}\text { Cap } \rightarrow \text { TRPV1 (transient); } \\
\text { AITC } \rightarrow \text { TRPA1 }(58 \%) ; \\
\text { diversity of chemical } \\
\text { activators: e.g., pH) }\end{array}$ & $\begin{array}{c}\text { AITC } \rightarrow \text { TRPA1 } \\
(36 \%)\end{array}$ & $\begin{array}{c}\text { Cap } \rightarrow \text { TRPV1 } \\
\text { (prolonged); histamine, } \\
\text { BK, PGE2 }\end{array}$ & $\begin{array}{c}\text { Cap } \rightarrow \text { TRPV1 (prolonged); } \\
\text { AITC } \rightarrow \text { TRPA1, 32\%; } \\
\text { MH sensitivity unmasked } \\
\text { by CAP; histamine, BK, PGE2 }\end{array}$ & $\begin{array}{c}16,25,60 \\
124,131\end{array}$ \\
\hline $\begin{array}{l}\text { Effect of injury/ } \\
\text { inflammation }\end{array}$ & $\begin{array}{l}\text { Nonuniform changes in } \\
\text { activity after burn: } \\
\text { hypoalgesia (glabrous); } \\
\text { sensitization (hairy) }\end{array}$ & Unknown & $\begin{array}{l}\text { Inflammation: hyperalgesia; } \\
\text { sensitive to mechanical } \\
\text { stimuli after injection } \\
\text { of inflammatory soup; } \\
\text { BK: sensitization }\end{array}$ & $\begin{array}{l}\text { Thresholds for } \\
\text { mechanical and heat } \\
\text { stimuli in "sensitive" } \\
\text { range; sensitization to } \\
\text { suprathreshold stimuli }\end{array}$ & $\begin{array}{c}26,60,106 \\
123,124 \\
128,132\end{array}$ \\
\hline Comments & $\begin{array}{l}\text { Heat responses independent } \\
\text { of TRPV1; may provide } \\
\text { neural code for magnitude } \\
\text { judgments of heat pain; } \\
\text { tribute to stimulus localization }\end{array}$ & & $\begin{array}{l}\text { Responsible for TRPV1-heat } \\
\text { hyperalgesia; not capable } \\
\text { of precise localization } \\
\text { of stimulus }\end{array}$ & $\begin{array}{l}\text { May be "C-H" fibers } \\
\text { with higher heat thresholds } \\
\text { or peripheral endings } \\
\text { deeper in the skin }\end{array}$ & 50,124 \\
\hline
\end{tabular}

Classification of nociceptors on the basis of mechanical sensitivity varies among investigators using different cut-off values and methods. For clarity, coldsensitive fibers are not included. Cap, capsaicin; CV, conduction velocity; PR, human subject pain ratings; +, immunoreactive.

at central and peripheral terminals (40,41). The soma expresses many molecular entities that are expressed in free nerve endings, central terminals, and axon (13). However, data from whole-cell soma recordings have been shown in a few cases to be at odds with behavioral or peripheral physiological data (e.g., heat transduction, refs. 42-44; and proton responsiveness, ref. 45). Although the underlying differences in these cases may be due to differential distribution of transduction molecules, it is also possible that nonneuronal peripheral components are required in vivo and lacking in dissociated neuronal cultures. This underscores the importance of corroborating results from cultured neurons with behavior and/or acute preparations retaining intact terminal fields. Labeling with retrograde dyes injected into the target tissue has enabled characterization of functional attributes of the soma of nociceptors innervating those tissues. The heterogeneity of functional phenotypes observed in isolated sensory cell bodies $(46,47)$ appears to reflect the variability observed in cutaneous nociceptor fiber types observed in studies in which recordings from fiber or soma during receptive field stimulation are combined with subsequent nociceptor labeling to identify terminal morphology $(48,49)$ and the expression of nocisensors (50), markers, and peptides (48) (Table 1). Nociceptors differentially express a variety of anatomical and biochemical markers (e.g., the expression of versican, the binding partner for the isolectin B4 [IB4]; ref. 51), however the functional significance of these markers, especially given striking species differences $(49,52)$, are unknown. Here, we will address how the functional heterogeneity of the nociceptor has an impact on the perception of pain. 
Table 2

Major heat and/or mechanosensitive nociceptor A-fiber classes

\begin{tabular}{|c|c|c|c|c|}
\hline & A-MH II & A-MH I & $A-M$ & References \\
\hline Percentage observed & $\sim 10$ (hairy skin) & $\sim 20$ (hairy skin) & $15-50$ & 50,55 \\
\hline $\mathrm{CV}(\mathrm{m} / \mathrm{s})$ & 11,15 (monkey) & 11, 25 (monkey) & 14 (monkey) & 55,57 \\
\hline $\begin{array}{l}\text { Correlation of heat } \\
\text { response and PR }\end{array}$ & $\begin{array}{l}\text { Yes; response is transient } \\
\text { (rapid onset }[<1 \mathrm{~s}] \text {, early peak } \\
\text { discharge }[<1 \mathrm{~s}] \text {, adapting); } \\
\text { fatigue to repeated stimuli }\end{array}$ & $\begin{array}{l}\text { Yes: Iong latency to } \\
\text { respond and late peak } \\
\text { discharge; shows } \\
\text { sensitization }\end{array}$ & NA & 55 \\
\hline Heat threshold & $43^{\circ} \mathrm{C}-47^{\circ} \mathrm{C}$ & $>53^{\circ} \mathrm{C}$ & NA & 55 \\
\hline $\begin{array}{l}\text { Correlation of mechanical } \\
\text { response to punctuate } \\
\text { stimulation and PR }\end{array}$ & $\begin{array}{l}\text { Yes but with } \\
\text { threshold offset }\end{array}$ & YES & YES & 78,132 \\
\hline Mechanical threshold & 11-15 bar (monkey) & 3.7-5 bar (monkey) & $\begin{array}{c}8.2 \mathrm{bar} \text { (monkey); } \\
25 \mathrm{mN} \text { (mouse) }\end{array}$ & $50,55,59$ \\
\hline Known chemical activators & Cap $\rightarrow$ TRPV1 & Cap insensitive & Cap insensitive & 57,59 \\
\hline Effect of injury/inflammation & Unknown & $\begin{array}{l}\text { Burn: heat sensitization, } \\
\text { hyperalgesia in glabrous skin; } \\
\text { may mediate } 2^{\circ} \text { punctate } \\
\text { mechanohyperalgesia }\end{array}$ & $\begin{array}{l}\text { Punctate hyperalgesia; } \\
\text { may mediate } 2^{\circ} \text { punctate } \\
\text { mechanohyperalgesia }\end{array}$ & $\begin{array}{c}19,55 \\
130,133\end{array}$ \\
\hline Comments & $\begin{array}{c}\text { Mediates first pain to } \\
\text { heat and provides precise } \\
\text { localization of stimulus; not } \\
\text { observed in glabrous skin; } \\
\text { eliminated in skin desensitized } \\
\text { by Cap }\end{array}$ & $\begin{array}{c}\text { Mediates } 2^{\circ} \text { punctate } \\
\text { hyperalgesia due to central } \\
\text { sensitization; May contribute } \\
\text { to slowly developing pain } \\
\text { to heat }\end{array}$ & $\begin{array}{c}\text { Mediates } 2^{\circ} \text { punctate } \\
\text { hyperalgesia due to central } \\
\text { sensitization; Most TRPV2+ } \\
\text { but insensitive to } 54^{\circ} \mathrm{C} \text {; } \\
\text { HTMs }\end{array}$ & $\begin{array}{l}50,55 \\
78,130\end{array}$ \\
\hline
\end{tabular}

For clarity, $\mathrm{A}-\mathrm{H}$ and $\mathrm{A}-\mathrm{M}_{\mathrm{i}} \mathrm{H}_{\mathrm{i}}$ ("MIA," ref. 26), which give long-lasting responses to capsaicin (57), are not included in this table. HTM, high threshold mechanoreceptor.

\section{The response of nociceptors to noxious stimuli}

Close proximity of distal extremities to a hot or cold surface, intense pressure or squeezing, and irritating chemicals can result in a subsecond somatopic withdrawal response. Activation of nociceptors requires that adequate stimuli depolarize peripheral terminals (producing a receptor potential) with sufficient amplitude and duration. This ensures that despite any attenuation and slowing of the receptor potential by passive propagation between the sites of transduction and action potential generation, information such as stimulus intensity will be encoded in the resulting train of impulses. Although the distance to action potential initiation is not known for fibers innervating the skin, action potential generation has been proposed to be at or near the site of transduction in $A \delta$ cold fibers innervating the guinea pig cornea (53). In this model, action potentials can be generated at differing distances from the terminal ending depending on the extent of depolarization of the fiber and resulting inactivation of voltage-gated channels involved in conduction (53). Theoretically, the depolarizing receptor potential can be accomplished by multiple membrane conductance changes and electrogenic pump activity. Since the electrochemical gradients for sodium $\left(\mathrm{Na}^{+}\right)$, calcium $\left(\mathrm{Ca}^{+2}\right)$, and chloride $\left(\mathrm{Cl}^{-}\right)(37)$ are more positive than the resting membrane potential in sensory neurons, the opening of ion channels permeable to these ions will cause the membrane potential to shift in the positive direction (depolarize). Since the electrochemical gradient for potassium $\left(\mathrm{K}^{+}\right)$is more negative than resting potential, closure of active potassium channels not only depolarizes the membrane potential but amplifies current-induced voltage fluctuations due to the resulting increase in membrane resistance (54).
The identification of the molecules that mediate or contribute to heat-, cold-, mechanical-, and chemical-induced generator potentials has been achieved by careful characterization of currents in native cells, the use of novel approaches to identify genes encoding channels and receptors, genome sequencing and bioinformatics, chemical tools (e.g., calcium dyes, pharmacological agents), and innovative genetic approaches. Although significant progress has been made in the study of heat and chemical transduction, many pieces of the puzzle are still missing (Table 3 and Figure 2).

\section{Transduction of noxious heat}

At least 5 classes of nociceptor reveal an increase in activity dependent on the intensity of the heat stimulus beyond the threshold for pain perception $\left(40^{\circ} \mathrm{C}-45^{\circ} \mathrm{C}\right)$ into the noxious range $(9,24)$. Microneurography studies on conscious human subjects have addressed whether activity in a particular fiber correlates with the psychological rating of pain. Under normal conditions, the activity in only a subset of heat-responsive fibers correlates to the degree of pain perceived (C-MH, A-MH type I, A-MH type II; Tables 1 and 2). A-fibers (A-MH Type II innervating hairy skin) responding to temperatures slightly cooler than the perceptual pain threshold for heat are proposed to mediate first pain in humans (55). These fibers rapidly activate, adapt during prolonged heat stimulation, fatigue between heat stimuli, and are sensitive to capsaicin (55-57), a selective agonist of the mammalian heat-activated nonselective cation (NSC) channel transient receptor potential VI (TRPV1) (58) (Table 3). In humans and monkeys, slowly developing second pain is evoked by activation of C-fibers and A-MH type I-fibers 
$(9,24)$, the latter requiring longer exposures to noxious temperatures to achieve maximal firing rates (Tables 1 and 2). Heatinduced $\mathrm{C}-\mathrm{MH}$ fiber activity in primates correlates with human pain perception in the absence of injury (9). In human glabrous skin, however, neither first pain (56) nor A-MH type II-fiber innervation is observed (59). Investigation of noxious heat transduction in animal models is complicated because the conservation of these pathways is unknown.

Although human $\mathrm{C}-\mathrm{MH}$ polymodal nociceptors are activated in a temperature range $\left(39^{\circ} \mathrm{C}-51^{\circ} \mathrm{C}\right)$ similar to recombinant TRPV1 (58) and have been reported to be transiently activated by capsaicin (60), genetic deletion of TRPV1 in mice only partially reduces noxious heat sensitivity in behavioral assays $(42,43)$ and has no effect on heat responsiveness of the C-fibers tested (42, 44, 49). This suggests that, at least in mice, heat sensors other than TRPV1 are the major contributors to acute heat-induced pain. Cultures of rodent sensory ganglia indicate expression of TRPV1 in approximately $50 \%$ of neurons (61) and $75 \%$ of small-medium diameter neurons (43), similar to the proportion of C-MH fibers in a skin-nerve-sensory ganglion-spinal cord preparation (49). Although functionally characterized mouse $\mathrm{C}-\mathrm{MH}$ neurons were not immunoreactive for TRPV1 (50), neurons with low expression levels may have been missed. Importantly, every identified mouse C-H neuron ( $10 \%$ of the population) revealed TRPV1-like immunoreactivity (50) and no functionally identified $\mathrm{C}-\mathrm{H}$ nociceptors were observed in TRPV1-deficient animals. This result cannot be explained by a phenotypic switch to C-MH fibers in these mice since mechanical sensitivity of the $\mathrm{C}$-fiber population was unchanged (50). Furthermore, noxious acute heat responses evoked in rat $\mathrm{C}-\mathrm{MH}$ saphenous fibers were not decreased by ruthenium red at concentrations that block the capsaicin response (45). In humans, the prolonged time course of the strong $\mathrm{C}-\mathrm{H}$ response to capsaicin applied to the receptive field matched the duration of the perceived pain (60) and is consistent with the results of rodent studies (50). Disparities regarding the contribution of TRPV1 to fiber subtype functionality (especially C-MH fibers) may depend on species, stimulation techniques, tissue preparation, and sensitivity of the assay. However, it is clear that acute heat responses are mediated by mechanisms in addition to TRPV1 activation, at least in mouse. In the context of tissue injury, however, polymodal C-MH fibers are certainly important in TRPV1-mediated thermal hyperalgesia, indicating that inflammation upregulates the contribution of TRPV1 to heat-evoked nocifensive behaviors in mouse (see below). TRPV2 (Table 3) has been suggested to mediate, at least in part, the receptor potential in A-MH type Ifibers, since it is activated by temperatures greater than $52^{\circ} \mathrm{C}$ in recombinant expression studies (62); however, the lack of selective pharmacological tools for manipulation of TRPV2 activity has hindered rigorous evaluation of this hypothesis. Transducers of heat stimuli into the noxious range other than TRPV1 and TRPV2 $(45,49)$ include other TRPV channels (TRPV3 and TRPV4) that have been reported to exist on sensory neurons (10) as well as constitutively active $\mathrm{K}^{+}$channels (KCNK2) inhibited by heat (63) (Table 3). Although TRPV3 undergoes dramatic sensitization to repeated heat stimuli, TRPV3 does not appear to be involved in agonist sensitization of C-fiber heat responses (44). Nocisensors directly activated by heat are also expressed on resident skin cells (e.g., TRPV3 and TRPV4 on keratinocytes; refs. 10 and 31) and cause the release of allogenic substances that indirectly influence nociceptor firing (64) (Table 3).

\section{Transduction of noxious cold}

Identifying the mechanisms used by nociceptors to transduce noxious cold has lagged behind progress in understanding heat transduction mechanisms (65). The intensity of cold pain in humans increases linearly with stimulus intensity between about $20^{\circ} \mathrm{C}$ and $0^{\circ} \mathrm{C}$. The threshold for pain perception to cold is much less precise than that for heat, but is about $15^{\circ} \mathrm{C}(66)$. There is tremendous variability in threshold for cutaneous cold-evoked fiber activity observed in mammals in part due to the rate of cooling (approximately $+30^{\circ} \mathrm{C}$ to $-18^{\circ} \mathrm{C}$; refs. $27,66-68$ ). Homeostatic processes engaged during in vivo studies (e.g., vasculature changes) and potential tissue damage occurring at subfreezing temperatures are likely to indirectly influence nociceptor responsiveness. Furthermore, measuring cold nocifensive behavior in animals has proven to be challenging, perhaps due to the prolonged exposure time in most assays (68).

Cooling the skin to $4{ }^{\circ} \mathrm{C}$ activates $\mathrm{A}$ - and C-fibers sensitive to innocuous cooling and cold-sensitive nociceptors $(27-29,67,69)$, consistent with the presence of two populations of cold-sensitive neurons observed in culture (70-72). Cool-sensitive nonnociceptive afferents are spontaneously active at normal skin temperature and their excitability increases with decreasing temperature $(53,67)$. The menthol-activated NSC channel TRPM8 (10) is responsible for the detection of innocuous cooling $(69,73,74)$ and contributes to spontaneous firing (69) in mice. The effective range for TRPM8-mediated cold coding extends from just below skin temperature into the noxious range $\left(10^{\circ} \mathrm{C}-15^{\circ} \mathrm{C}\right.$ and below; ref. 10). Although mouse studies have yielded conflicting results regarding the requirement of TRPM8 in behavioral responses to noxious stimuli, more recent work using a novel cold-plate assay convincingly demonstrates a role for mouse TRPM8 in sensing noxious cold (75). Furthermore, the analgesic effects of cold temperature $\left(17^{\circ} \mathrm{C}\right)$ were lost in mice lacking TRPM8 in the context of formalin-induced inflammation (74). Whether TRPM8-mediated analgesia is dependent on peripheral and/or central sites of action is unknown but may be addressed now that TRPM8expressing neurons and their peripheral and central fibers can be visualized by GFP expression driven by the TRPM8 promoter $(76,77)$. Importantly, studies in humans and mice reveal species differences in pathways sensing innocuous cold: A-fiber block completely suppresses the cold response in humans (78), yet the majority of TRPM8-expressing fibers responsible for innocuous cold transduction in mice have small diameters $(76,77)$

Noxious cold stimuli activate NSC currents and calcium influx $(10,79)$ and decrease $\mathrm{K}^{+}$channel activity $(80)$ and $\mathrm{Na}^{+} / \mathrm{K}^{+}$-ATPase function (65) (Table 3). The temporal dissociation of the qualities of pain/ache vs. prickle/heat to noxious cold $\left(3^{\circ} \mathrm{C}\right)$ suggest underlying differences in transduction mechanisms or information processing (66). The cation channel TRPA1 (10) has been proposed to play a role in this process because it has a threshold near $17^{\circ} \mathrm{C}$, is expressed in nociceptors together with TRPV1 (10), and is required for cold sensation in mice $(81,82)$. Human genetic studies have suggested TRPA1 contributes to variation in cold-pain sensitivity (5). Although TRPA1 may respond to cold indirectly through cold-induced intracellular calcium release (10), slow temperature ramps can activate TRPA 1 in excised patches in the absence of calcium $(82,83)$. However, the contribution of TRPA1 to cold sensation is debated since TRPA1 activation was not observed in a heterologous expression system or cultured TG neurons to which relatively short cold stimuli to $5^{\circ} \mathrm{C}$ were applied (84), and not all 
Table 3

Proposed ion channel sensors of cutaneous noxious stimuli

\begin{tabular}{|c|c|c|c|c|c|}
\hline $\begin{array}{l}\text { Noxious } \\
\text { stimulus }\end{array}$ & $\begin{array}{l}\text { Transduction } \\
\text { channel }\end{array}$ & $\begin{array}{l}\text { Evidence for role in } \\
\text { acute nociception }\end{array}$ & $\begin{array}{c}\text { Role in } \\
\text { hyperalgesia }\end{array}$ & Comments & Refs \\
\hline \multirow[t]{6}{*}{ Heat $\geq 43^{\circ} \mathrm{C}$} & $\begin{array}{l}\text { TRPV } 1 \geq 43^{\circ} \mathrm{C} \\
\text { (unsensitized); } \\
\text { specific receptor } \\
\text { for sub- } \mu \text { M Cap }\end{array}$ & $\begin{array}{l}\text { Chemical activation (Cap, } \\
\text { resiniferatoxin); heat nociception } \\
\text { by activating } \mathrm{C}-\mathrm{H} \text { fibers (mouse); } \\
\text { reduced central wide dynamic } \\
\text { range neuron response } \\
\text { to } 49^{\circ} \mathrm{C} \text { in null mice }\end{array}$ & $\begin{array}{l}\text { Major contributor to thermal (heat) } \\
\text { after carrageenan or CFA-induced } \\
\text { inflammation; heat threshold } \\
\text { decreased by inflammatory mediators } \\
\text { (e.g., BK, NGF-mediated phosphorylation } \\
\text { via P-p38); after burn, heat hyperalgesia } \\
\text { reduced in KO; upregulation and } \\
\text { enhanced activity in inflammation }\end{array}$ & $\begin{array}{l}\text { Only heat receptor that } \\
\text { releases CGRP and substance P } \\
\text { in periphery when activated; } \\
\text { Cap induces predominantly } \\
\text { stinging and burning pain }\end{array}$ & $\begin{array}{l}10,34 \\
42-44 \\
50,134\end{array}$ \\
\hline & $\begin{array}{l}\text { TRPV } 2 \geq 52^{\circ} \mathrm{C}, \\
\text { recombinant }\end{array}$ & $\begin{array}{l}\text { No evidence for a loss of heat } \\
\text { sensitive fibers in mice lacking } \\
\text { TRPV2 together with TRPV1 }\end{array}$ & ND & $\begin{array}{c}\text { Proposed to mediate heat response } \\
\text { in A-MH type II-fibers } \\
\text { (human/primate) }\end{array}$ & 49 \\
\hline & $\begin{array}{l}\text { TRPV3; threshold } \\
32^{\circ} \mathrm{C}-39^{\circ} \mathrm{C} \text { into } \\
\text { noxious range }\end{array}$ & $\begin{array}{l}\text { Heat: increased withdrawal } \\
\text { latency on hot plate } \geq 50^{\circ} \mathrm{C}\end{array}$ & $\begin{array}{l}\text { Null mice reveal no deficits } \\
\text { in thermal (heat) or mechanical } \\
\text { hyperalgesia induced by CFA or BK } \\
\text { and formalin-induced behaviors }\end{array}$ & $\begin{array}{l}\text { Reveals strong sensitization by } \\
\text { repeated heating; mediates ATP } \\
\text { release from keratinocytes and } \\
\text { PGE }_{2} \text { release from keratinocytes } \\
\text { overexpressing TRPV3 }\end{array}$ & $64,135-138$ \\
\hline & $\begin{array}{l}\text { TRPV4; threshold } \\
27^{\circ} \mathrm{C}-34^{\circ} \mathrm{C} \text { into } \\
\text { noxious range }\end{array}$ & $\begin{array}{l}\text { No contribution to } 50^{\circ} \mathrm{C} \text {-induced } \\
\text { spike frequency at } 40^{\circ} \mathrm{C} \text {; } \\
\text { no phenotype on hot plate to } 50^{\circ} \mathrm{C}\end{array}$ & $\begin{array}{l}\text { Thermal (heat): slight increase in } \\
\text { withdrawal latency at } 45^{\circ} \mathrm{C}-46^{\circ} \mathrm{C} \text {; } \\
\text { activated by concerted action of } \\
\text { components in inflammatory soup }\end{array}$ & $\begin{array}{c}\text { Protein has been detected in DRG } \\
\text { that depends on an intact TRPV4 } \\
\text { gene; high expression in keratinocytes }\end{array}$ & $\begin{array}{c}10,67 \\
139-142\end{array}$ \\
\hline & $\begin{array}{l}\text { KCNK2 (TREK-1) } \\
30^{\circ} \mathrm{C}-45^{\circ} \mathrm{C}\end{array}$ & $\begin{array}{c}\text { Null mice reveal: enhanced heat- } \\
\text { dependent }\left(30^{\circ} \mathrm{C}-45^{\circ} \mathrm{C}\right) \text { saphenous } \\
\mathrm{C} \text {-fiber activity; decreased thermal } \\
\left(46^{\circ} \mathrm{C}-50^{\circ} \mathrm{C}\right) \text { tail withdrawal latency; } \\
\text { higher percentage of heat- } \\
\text { sensitive/TRPV1-negative fibers }\end{array}$ & $\begin{array}{l}\text { Recombinant channel activity inhibited } \\
\text { by } \mathrm{H}^{+}, \mathrm{LPA} \text {; Inflammation increased } \\
\text { heat }\left(46^{\circ} \mathrm{C}\right) \text { (but not cold) hyperalgesia } \\
\text { in C-MH fibers in null mice; LPA and } \\
\text { protons inhibit channel activity }\end{array}$ & $\begin{array}{l}\text { 2-pore potassium channel reduced } \\
\text { activity causes increased excitability; } \\
\text { contributes to suppression of } \\
\text { heat activation of C-MH fibers; } \\
\text { negatively regulated by } \mathrm{G}_{\mathrm{s}} \text { and } \mathrm{G}_{\mathrm{q}} \\
\text { protein-coupled receptors, such } \\
\text { as } \mathrm{PGE}_{2} \text {, serotonin, and glutamate }\end{array}$ & $\begin{array}{c}63,143 \\
144\end{array}$ \\
\hline & KCNK4 (TRAAK) & $\begin{array}{l}\text { Null mice reveal: higher percentage } \\
\text { of heat-sensitive/TRPV1-negative } \\
\text { fibers and heat hyperalgesia }\end{array}$ & $\begin{array}{l}\text { Null mice reveal heat }\left(46^{\circ} \mathrm{C}\right) \\
\text { hyperalgesia after carrageenan }\end{array}$ & Two pore potassium channel & 144 \\
\hline \multirow[t]{3}{*}{ Cold } & $\begin{array}{l}\text { TRPM8; threshold near } \\
26^{\circ} \mathrm{C} \text { and active into } \\
\text { the noxious range }\end{array}$ & $\begin{array}{l}\text { Severe deficit in cooling-induced } \\
\text { behavior and sensory neuronal } \\
\text { responses in null mice; contributes } \\
\text { to avoidance of moderately low } \\
\text { temperature; contributes to avoidance } \\
\text { at noxious cold temperatures } \\
\text { and cold hypersensitivity }\end{array}$ & $\begin{array}{l}\text { Contributes to cold allodynia } \\
\text { in CFA model of inflammation }\end{array}$ & $\begin{array}{l}\text { Predominant detector of innocuous } \\
\text { cold in vivo; responsible for the } \\
\text { analgesic effect produced by cold } \\
\text { or chemical cooling compounds }\end{array}$ & $\begin{array}{c}10,69 \\
73-75 \\
145\end{array}$ \\
\hline & $\begin{array}{l}\text { TRPA1; moderately } \\
\text { specific receptor } \\
\text { for mid- } \mu \text { M AITC }\end{array}$ & $\begin{array}{l}\text { Contributes to nocifensive behaviors } \\
\text { on } 0^{\circ} \mathrm{C} \text { cold plate and acetone- } \\
\text { induced nocifensive behaviors; } \\
\text { and cold hypersensitivity at } 10^{\circ} \mathrm{C}\end{array}$ & $\begin{array}{l}\text { Contributes to CFA-induced cold hyperalgesia } \\
\text { and BK-induced hyperalgesia; null mice reveal } \\
\text { increased threshold to punctate mechanical stimuli } \\
\text { (von Frey) and reduced inflammatory hyperalgesia }\end{array}$ & $\begin{array}{l}\text { Controversial (see text); does not } \\
\text { contribute to heat hyperalgesia } \\
\text { during CFA-induced inflammation }\end{array}$ & $\begin{array}{l}10,75,81 \\
82,85 \\
146-148\end{array}$ \\
\hline & KCNK4 (TRAAK) & $\begin{array}{l}\text { Together with KCNK2 (but not alone) } \\
\text { contributes to noxious cold-induced } \\
\text { C-fiber activity (lowered threshold) } \\
\text { and behavior }\end{array}$ & ND & $\begin{array}{l}\text { Combination of TREK-1 } \\
\text { and TRAAK important }\end{array}$ & 144 \\
\hline \multirow[t]{7}{*}{$\begin{array}{l}\text { Intense punctate } \\
\text { and/or pinch } \\
\text { pressure }\end{array}$} & $\begin{array}{l}\text { KCNK2 } \\
\text { (TREK-1) }\end{array}$ & $\begin{array}{l}\text { Contributes to von Frey punctate } \\
\text { mechanical-induced pain, } \\
\text { but not pressure-induced pain }\end{array}$ & $\begin{array}{l}\text { Null mice reveal inflammation-induced } \\
\text { mechanical (von Frey) hyperalgesia } \\
\text { and reduced } \mathrm{PGE}_{2} \text {-induced pain }\end{array}$ & $\begin{array}{l}\text { Hypertonic }(10 \%) \text { saline- } \\
\text { induced pain reduced } \\
\text { in null mice }\end{array}$ & 63 \\
\hline & KCNK4 (TRAAK) & $\begin{array}{l}\text { Contributes to punctate von Frey- } \\
\text { induced pain; together with KCNK2 } \\
\text { contributes to osmotic pain }\end{array}$ & ND & $\begin{array}{c}\text { Combination of TREK- } 1 \text { and } \\
\text { TRAAK important }\end{array}$ & 144 \\
\hline & TRPV4 & $\begin{array}{l}\text { TRPV4 KO: reduced response } \\
\text { to tail clamp }\end{array}$ & Mechanical hyperalgesia & $\begin{array}{l}\text { Although activated by hypotonicity, } \\
\text { there is lack of consensus for a role } \\
\text { of TRPV4 in noxious mechanical stimulus } \\
\text { transduction; protein has been detected in } \\
\text { DRG that depends on an intact TRPV4 gene }\end{array}$ & 142,149 \\
\hline & TRPA1 & $\begin{array}{l}\text { Cutaneous nociceptor fibers from } \\
\text { TRPA1-null mice exhibit lower firing } \\
\text { rates in response to mechanical stimuli }\end{array}$ & $\begin{array}{l}\text { Mechanical hyperalgesia BK-induced } \\
\text { reduction in mechanical withdrawal } \\
\text { threshold required TRPA1 }\end{array}$ & $\begin{array}{l}\text { A direct effect of mechanical stimuli } \\
\text { on mammalian TRPA1 has not } \\
\text { been demonstrated }\end{array}$ & $\begin{array}{l}81,147 \\
148\end{array}$ \\
\hline & TRPV1 & $\begin{array}{l}\text { Null mice have normal threshold } \\
\text { for punctuate and pinch stimuli }\end{array}$ & $\begin{array}{l}\text { After burn, mechanical hyperalgesia } \\
\text { reduced in KO; BK-induced reduction in } \\
\text { mechanical withdrawal threshold required } \\
\text { TRPV1; no defects in mechanical sensitivity } \\
\text { after AITC or CFA injection in null mice }\end{array}$ & Role in mechanical hyperalgesia & $\begin{array}{c}42,85 \\
134\end{array}$ \\
\hline & Kv3.4 & $\begin{array}{l}\text { Mechanical hyperalgesia after i.t. } \\
\text { antisense ODN injection (rat lumbar } \\
\text { DRG); no effect on heat response }\end{array}$ & ND & $\begin{array}{l}\text { Reduced activity causes } \\
\text { increased hyperalgesia }\end{array}$ & 150 \\
\hline & Kv4.3 & $\begin{array}{l}\text { Mechanical hyperalgesia after i.t. } \\
\text { antisense ODN injection (rat lumbar } \\
\text { DRG); no effect on heat response }\end{array}$ & ND & $\begin{array}{l}\text { Reduced activity causes } \\
\text { increased hyperalgesia }\end{array}$ & 150 \\
\hline
\end{tabular}


A
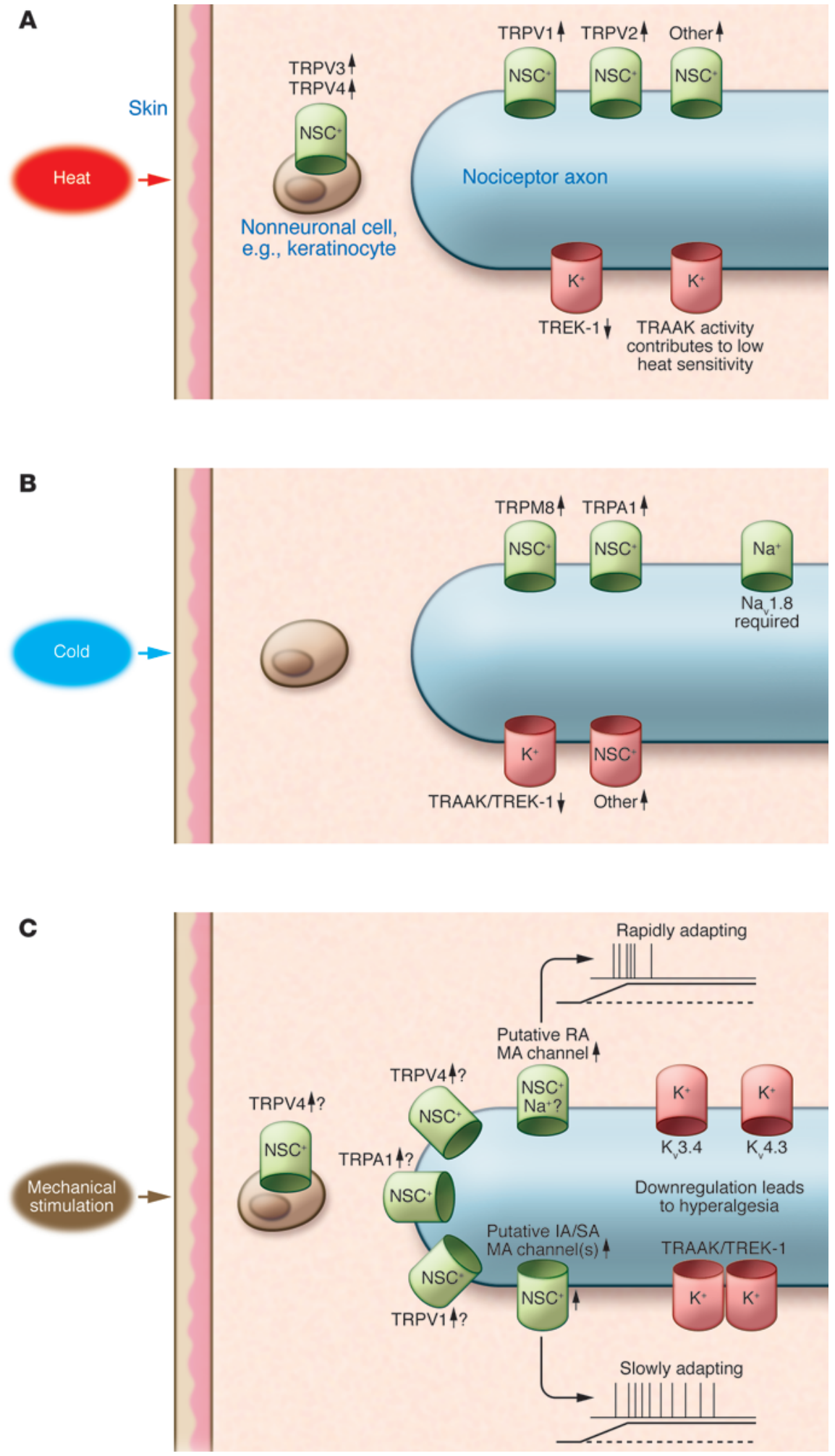

\section{Figure 2}

Known or proposed transduction mechanisms in uninjured mammalian nociceptor peripheral terminals. Ion channels that transduce heat (A), cold (B), and mechanical stimuli (C) are depicted. Stimuli are presented to the skin, which is depicted as containing representative nonneuronal cells (such as keratinocytes) (brown cells) and the free nerve endings of nociceptor axons (blue). Arrows next to channels indicate whether their activity is increased or decreased upon stimulation. Note that these nocisensors are not necessarily coexpressed in the same terminal. The curved arrow in $\mathbf{C}$ refers to the transducer(s) and other channels and molecules that contribute to the firing pattern (e.g., rapidly adapting vs. slowly adapting) in these fibers. Molecularly unidentified channels with indicated ion permeabilities inside drawing of channel are referred to as "putative RA MA channel" and "putative IA/SA MA channel." MA, mechanically activated; $R A$, rapidly adapting; IA, intermediate adapting; SA, slowly adapting. mouse lines constitutively lacking TRPA1 reveal a cold phenotype in behavioral and neural assays (85). However, two independent studies recently demonstrated a role of TRPA1 in noxious cold sensitivity $(75,82)$. TRPA1 is established as a general sensor for noxious irritating electrophilic compounds (including allyl iso- thiocyanate [mustard oil] [AITC] and cinnamaldehyde, the active pungent ingredients in hot mustard and cinnamon, respectively; refs. 84 and 86) and is sensitized by inflammatory mediators (87). These electrophilic agonists open an integral channel pore by covalent binding to the intracellular $\mathrm{N}$ terminus of the channel protein 
$(88,89)$. Importantly, endogenous reactive chemicals are also effective agonists of TRPA1 (90). How TRPA1-expressing neurons might mediate the burning sensation of hot mustard (AITC) may be explained by anatomical and psychophysical results: AITC is a strong chemical activator of a subset of TRPV1-expressing neurons, and activity in peripheral fibers transmitting information about cold stimuli in the presence of an A-fiber block (presumably C-fibers) evoke burning, aching, and pricking qualities (67). Interestingly, the activation of some cold fibers by noxious heat may be the basis for the paradoxical cold sensation felt by stimulating cold spots with noxious heat stimuli (67).

\section{Transduction of noxious mechanical stimuli}

Whereas heat- and chemical-induced nociceptor responses correlate with pain perception in humans $(9,24)$, mechanical stimulation of C-MH (24) and rapidly adapting A-HTM (18) fibers may not (24) (Tables 1 and 2). The perception of pinprick pain intensity, however, is related to activity in capsaicin-insensitive A-fiber nociceptors (e.g., A-M and A-MH type I) (78). Transduction channels mediating mammalian noxious (and innocuous) mechanical stimuli have been elusive $(5,91,92)$. Transduction in soma membranes on a submillisecond time scale suggests direct gating by pressure of ion channels with NSC and possibly $\mathrm{Na}^{+}$permeability (91). No orthologs for the well-studied prokaryotic mechanosensitive channels MscL and MscS are present in mammalian genomes (93). In addition, there is no strong evidence that mammalian orthologs of invertebrate components of structures involved in mechanosensation (92) are the transduction channel in cutaneous sensory neurons, although acid-sensitive ion channels (ASICs) appear to play a role (11). Some progress has been made in the identification of proteins (e.g., stomatin-like protein 3; ref. 94) involved in sensing innocuous touch, but their genetic deletion in mouse does not compromise behavioral responses to noxious pressure. TRP channels are candidates based on expression and functional similarities to evolutionary counterparts, but whether these contribute to the molecular sensor/transducer or function in a sensitizing role is still unclear (11) (Table 3). The challenges encountered in assigning a role for transducers of noxious mechanical stimuli include the efficacy of stimulation protocols applied in behavioral and ex vivo tissue assays (e.g., phenotypes can differ when challenged with thin calibrated von Frey nylon filaments vs. distributed pinch that may also induce local ischemia; ref. 95), the suppressive influence of innocuous A-fiber mechanosensitive inputs at a systems level (18), and the extrapolation of cellular assays to nociception (e.g., poking, ref. 96; stretching, ref. 97; hypo-osmotic-induced swelling, ref. 98). This topic is reviewed in more detail elsewhere $(12,19,91-93)$.

\section{Conduction}

Nociceptors express a wide variety of voltage-gated channels (e.g., $\mathrm{Na}_{v}, \mathrm{Ca}_{v}, \mathrm{~K}_{\mathrm{v}}$ ) that transduce the receptor potential into an action potential or, more commonly, a set of action potentials that encode the intensity of a noxious stimulus applied within their receptive fields. There are 9 known $\mathrm{Na}_{v}, 10 \mathrm{Ca}_{v}$, and $40 \mathrm{~K}_{\mathrm{v}}$ genes in mammals (http://www.iuphar-db.org/DATABASE/), many of which have multiple splice variants with different functional characteristics (99). Cell excitability and firing behavior (e.g., threshold for action potential generation, action potential and undershoot amplitude and duration, and maximal firing frequency) depend on the complement of these channels as well as those contributing to frequency modulation (e.g., hyperpolarization-activated cyclic nucleotide-gated cation channel $[\mathrm{HCN}]$ and A-type $\mathrm{K}_{\mathrm{v}} 4.3$ and $\mathrm{K}_{\mathrm{v}} 3.4$ channels) (54). For instance, nociceptors responsive to noxious cold require the expression of the tetrodotoxin-resistant (TTX-resistant) $\mathrm{Na}_{\mathrm{v}} 1.8$ channel at the peripheral terminal (100), and mice lacking $\mathrm{Na}_{\mathrm{v}} 1.8$ and $\mathrm{Na}_{\mathrm{v}} 1.7$ display deficits in mechanosensation $(95,101)$. Peripheral CGRP release by inflammatory mediators is unaffected by TTX, suggesting an important role of TTX-resistant $\mathrm{Na}_{\mathrm{v}}$ in regulated pain thresholds, consistent with their robust modulation by bradykinin (BK) and $\mathrm{PGE}_{2}(102)$ (see below). Since enhanced excitability of primary sensory neurons in inflammatory and pathologic pain states is a major contributor to the perception of pain, specific pharmacological agents that specifically dampen aberrant activity are desirable in the design of pain therapeutics. To this end, an understanding of species-specific differences is critical, as exemplified by the dramatically different phenotypes in mice and humans lacking $\mathrm{Na}_{v} 1.7$ : although mice lacking $\mathrm{Na}_{v} 1.7$ show a mechanosensory (pinch) and formalin-induced (5\%) pain phenotype (103), humans lacking $\mathrm{Na}_{v} 1.7$ are insensitive to pain altogether (104).

\section{Central modulation}

Nociceptors release a variety of substances from their central terminals that have the potential of exciting second-order neurons through multiple mechanisms. Fast and slow synaptic transmission are mediated in large part by glutamate and peptides (e.g., substance $\mathrm{P}, \mathrm{CGRP})$, respectively $(7,38)$. Of particular importance to pain perception is the plasticity in synaptic strength (i.e., the ability to enhance homosynaptic as well as heterosynaptic connections) between primary afferents and the relay and interneurons they drive, presynaptic and postsynaptic modulation by descending facilitatory and inhibitory pathways in the spinal cord, and the efferent aspects of nociceptor function activated by strong GABAergic/glycinergic depolarization of presynaptic terminals leading to the dorsal root reflex $(37,105)$. Anterograde transmission of action potentials from the spinal cord to the periphery results in release of peptides and other inflammatory mediators in the skin and exacerbates nociceptor excitability and pain (see below). It is at the spinal level that nonnociceptive neurons are recruited by strong nociceptor activation through functional modulation of local circuits (105).

\section{Adaptive and maladaptive shifts in pain threshold}

Injury to the skin induces protective physiological responses aimed at decreasing the likelihood of exacerbating the injury. After an injury induced by pungent chemicals (e.g., capsaicin, mustard oil) and burn, stimulation of the injured area produces enhanced pain to noxious stimuli (primary mechanical and thermal hyperalgesia) dependent on C-fiber activity that manifests as a decrease in threshold to activate $\mathrm{C}-\mathrm{MH}$ fibers and to perceive pain $(9,19,106)$. Immediately surrounding the injured area, a zone of flare (reddening) develops and stimulation of even a larger secondary zone produces pain in response to normally innocuous stimuli (e.g., brush stroke) (secondary mechanical allodynia) as well as enhanced responsiveness to noxious mechanical (secondary mechanical hyperalgesia) and thermal (heat) hyperalgesia if spatial summation is invoked (secondary thermal hyperalgesia) $(21,105,107)$. Here, noxious punctate stimulation of C-nociceptors induces secondary mechanical hyperalgesia mediated by A-nociceptors (7) and innocuous dynamic mechanical stimuli (gentle stroking) provokes nonnociceptor A-fiber-mediated pain 
(108). Cellular mechanisms underlying this complicated response involve both peripheral and central processes $(14,38,105,107)$ and require nociceptor input, particularly A-MH and C-MH fibers $(19,91,105)$. After a burn, A-MH fibers (most likely type I) mediate primary heat hyperalgesia in glabrous skin (9).

What are the cellular mechanisms mediating hyperalgesia? Electrical stimulation of the majority of C-polymodal fibers produced plasma extravasation in their peripheral receptor field (109). Centrally propagating impulses can antidromically invade peripheral arborizations innervating other areas in the afferent's receptive field (axon reflex), causing the release of peptides (e.g., substance P, CGRP, somatostatin) and/or other bioactive substances from the terminal (e.g., cytokines) into the interstitial tissue (17). The released substances produce a myriad of autocrine or paracrine effects on endothelial, epithelial, and resident immune cells (Langerhans), which lead to arteriolar vasodilatation ("flare," via CGRP) and/or increased vascular permeability and plasma extravasation from venules (edema, via substance $P$ ). Liberated enzymes (e.g., kallikreins) and blood cells (e.g., platelets, mast cells) further contribute to the accumulation of inflammatory mediators and neurogenic inflammation $(110,111)$. A large variety of substances feed back onto nociceptors innervating the injured region and sensitize peripheral terminals by direct and indirect actions at ion channels, receptors, and second messenger cascades $(87,102,111$, 112). The mechanisms by which inflammatory mediators recruit "silent" $\mathrm{C}-\mathrm{M}_{\mathrm{i}} \mathrm{H}_{\mathrm{i}}$ fibers by endowing these fibers with prolonged mechanical and heat sensitivity $(25,60)$ is unknown but may involve long-lasting alterations in second messenger signaling cascades and sensitization of nocisensors. Decreased thermal and chemical thresholds in the primary area are due in part to sensitization of TRPV1 and TRPA1 by numerous components of the "inflammatory soup" including BK $(36,85-87,112)$. Although TRPV1 is not the only transducer of acute noxious heat, it is the major contributor to the development of heat hyperalgesia, perhaps due to its expression in polymodal neurons capable of inducing neurogenic inflammation and modifying central connections $(42,43)$. As a polymodal nocisensor, TRPV1 is the target for acute acid responsiveness in the skin of mice, although species differences are apparent (113). A recently described phenomenon ("hyperalgesic priming") evoked by cytokine- and neurotrophininduced recruitment of $\mathrm{G}_{\mathrm{i} / \mathrm{o}}-\mathrm{PKC \varepsilon}$ signaling in nociceptors can produce prolonged sensitization and mechanical hyperalgesia and may contribute to chronic pain (114). Prolonged pain perception observed in inflammatory pain models is generally believed to be produced by ongoing nociceptor activity (15); formalin, for instance, produces nocifensive behaviors through its activation of TRPA1 $(115,116)$. Secondary hyperalgesia to punctate pinprick stimuli is mediated at least in part by capsaicin-insensitive A-fiber nociceptors (e.g., A-MH type I and A-M; Table 2) by central sensitization processes $(78,108)$.

\section{Do labeled lines transmit noxious stimulus information?}

Determining the extent to which pain qualities are dependent on the activation of subpopulations of neurons and intensity coding poses a considerable challenge and is an active area of research (13). Psychophysical studies on spinal cord injury patients suffering from partial or complete loss of thermal sensitivity support a model in which both pain-specific pathways and nonnociceptive pathways are integrated (117). Significant crosstalk between these pathways exists at multiple levels including stimulus transduction
(118), peripheral terminals during neurogenic inflammation, and central connections during central sensitization and may underlie paradoxical temperature sensation. To address the extent by which particular nociceptive signaling pathways encode particular modalities, a number of approaches have been taken. Genetically encoded tracers have enabled visualization of specific subpopulations of sensory neurons (e.g., Mrgpr family, ref. 30; TRPM8, refs. 76 and 77) and determination of their innervation patterns as well as cellular function. Pharmacologic and hereditary genetic ablations have defined the role of nociceptors in pain but until recently have included multiple or entire nociceptor populations (e.g., capsaicininduced ablation of TRPV1-expressing neurons; refs. 42 and 119) or sensory and autonomic populations (2). Genetically mediated ablation using toxins (e.g., diphtheria A) transcribed by promoters of genes expressed in specific neuronal subtypes (e.g., $\mathrm{Na}_{\mathrm{v}} 1.8$ expressing neurons, ref. 120) provides a means to address the contributions of particular cells to acute nociception and hyperalgesia and allodynia after injury.

Mice expressing diphtheria toxin under the $\mathrm{Na}_{\mathrm{v}} 1.8$ promoter reveal significant loss of sensory neurons ( $85 \%$ and $13 \%$ of unmyelinated and myelinated neurons, respectively, consistent with $\mathrm{Na}_{\mathrm{v}} 1.8$ expression in most nociceptors as well as some myelinated sensory neurons). These mice are unresponsive to acute noxious mechanical (pressure-induced, not punctate) and cold stimuli and defective in the development of inflammatory pain, but are normal with regard to acute responsiveness to heat stimuli and the ability to develop neuropathic pain (120). These data are remarkably consistent with gene-deletion studies (103). The sensitivity of $\mathrm{C}-\mathrm{MH}$ fibers innervating hairy skin to cold, heat, and mechanical stimuli is reduced in mice constitutively lacking MrgprD-expressing cells reported to be TRPV1 and peptide negative (121). However, when genetic ablation of this population of cells is done in adulthood, behavioral deficits were observed to mechanical but not thermal stimuli (122). An additive loss of both mechanicaland heat-induced nocifensive behaviors was achieved after further pharmacologic ablation of central TRPV $1^{+}$terminals, suggesting a separation of mechanical and thermal modalities at all levels of sensory processing in the pain pathways subserved by MrgprDand TRPV1-expressing cells (122). The extent to which this separation is maintained for other murine nociceptor populations is a subject of active research.

\section{Future challenges}

Despite significant progress in understanding the complexities of mammalian nociception and pain perception in the last half century, our knowledge is far from complete with regard to the identity of the full complement of sensors of noxious stimuli (particularly with regard to mechanotransduction), the role of nociceptor heterogeneity in physiological and pathological pain, the coding of the quality of the stimulus, and the modulation of pain pathways by peripheral and central mechanisms. A focus on mechanisms underlying thermal nociception and hyperalgesia is in large part due to the identification of the TRP family of channels. The future identification of elusive mechanotransducers in somatosensory neurons will likewise thrust the direction of research toward a cellular/molecular understanding of mechanical hyperalgesia and allodynia. The application of genetic technologies and pharmacological approaches to understanding the contributions of molecules, signaling pathways, and cell populations to nocifensive behaviors to particular stimulus modalities in normal 
and pathophysiological states in rodents will inspire hypotheses that ultimately must be tested in humans.

\section{Acknowledgments}

We gratefully acknowledge Jorg Grandl, Daniel Dubin, Takashi Miyamoto, and Arturo Galvez for helpful discussion. The work was supported by NIH grants R01 DE016927 and R01 NS046303 (to A. Patapoutian).

Address correspondence to: Adrienne Dubin, 10550 N. Torrey Pines Road, La Jolla, California 92037, USA. Phone: 858.775.6632; Fax: 959.784.9107; E-mail: adubin@scripps.edu.
1. Terman GW, Bonica JJ. Spinal mechanisms and their modulation. In: Loeser JD, Butler SH, Chapman CR, Turk DC, eds. Bonica's Management of Pain. 3rd ed. Philadelphia, Pennsylvania, USA: Lippincott Williams and Wilkins; 2003:73.

2. Axelrod FB, Hilz MJ. Inherited Autonomic Neuropathies. Semin Neurol. 2003;23(4):381-390.

3. Price D, Dubner R. Mechanisms of first and second pain in the peripheral and central nervous systems. J Invest Dermatol. 1977;69(1):167-171.

4. LaCroix-Fralish ML, Mogil JS. Progress in genetic studies of pain and analgesia. Annu Rev Pharmacol Toxicol. 2009;49:97-121.

5. Foulkes T, Wood JN. Pain genes. PLoS Genet. 2008;4(7):e1000086.

6. Eccleston C. Role of psychology in pain management. Br J Anaesth. 2001;87(1):144-152.

7. Willis WD, Coggeshall RE. Sensory Mechanisms of the Spinal Cord. 3rd ed. New York, New York, USA: Kluwer Academic/Plenum; 2004.

8. Robinson DR, Gebhart GF. Inside Information: The Unique Features of Visceral Sensation. Mol Interv. 2008;8(5):242-253.

9. Raja SN, Meyer RA, Campbell JN. Peripheral mechanisms of somatic pain. Anesthesiology. 1988;68(4):571-590.

10. Patapoutian A, Tate S, Woolf CJ. Transient receptor potential channels: targeting pain at the source. Nat Rev Drug Discov. 2009;8(1):55-68.

11. Smith E, Lewin G. Nociceptors: a phylogenetic view. 2009. J Comp Physiol A Neuroethol Sens Neural Behav Physiol. 2009;195(12):1089-1106.

12. Woolf CJ, Ma Q. Nociceptors-noxious stimulus detectors. Neuron. 2007;55(3):353-364.

13. Basbaum AI, Bautista DM, Scherrer G, Julius D. Cellular and molecular mechanisms of pain. Cell. 2009;139(2):267-284.

14. Hucho T, Levine JD. Signaling pathways in sensitization: toward a nociceptor cell biology. Neuron 2007;55(3):365-376.

15. Le Bars D, Gozariu M, Cadden SW. Animal models of nociception. Pharmacol Rev. 2001;53(4):597-652.

16. Namer B, Handwerker H. Translational nociceptor research as guide to human pain perceptions and pathophysiology. Exp Brain Res. 2009;196(1):163-172.

17. Mense S, et al. Anatomy of nociceptors. In: Bushnell MC, Smith DV, Beauchamp GK, Firestei SJ, eds. The Senses: A Comprehensive Reference. New York, New York, USA: Academic Press; 2008:11-41.

18. Andrew D, Greenspan JD. Peripheral coding of tonic mechanical cutaneous pain: comparison of nociceptor activity in rat and human psychophysics. J Neurophysiol. 1999;82(5):2641-2648.

19. Lewin GR, Moshourab R. Mechanosensation and pain. J Neurobiol. 2004;61(1):30-44.

20. Zimmermann K, et al. Phenotyping sensory nerve endings in vitro in the mouse. Nat Protoc 2009;4(2):174-196.

21. Schmelz M. Translating nociceptive processing into human pain models. Exp Brain Res. 2009 196(1):173-178

22. Djouhri L, Lawson SN. A[beta]-fiber nociceptive primary afferent neurons: a review of incidence and properties in relation to other afferent A-fiber neurons in mammals. Brain Res Brain Res Rev. 2004;46(2):131-145

23. Kumazawa T, Mizumura K, Kruger L, eds. The Polymodal Receptor-- A Gateway to Pathological Pain. Prog ress in Brain Research. Vol. 113. New York, New York,

\section{USA: Elsevier; 1996}

24. Van Hees J, Gybels J. C nociceptor activity in human nerve during painful and non painful skin stimulation. J Neurol Neurosurg Psychiatry. 1981;44(7):600-607.

25. Schmidt R, Schmelz M, Forster C, Ringkamp M, Torebjörk E, Handwerker H. Novel classes of responsive and unresponsive $\mathrm{C}$ nociceptors in human skin. J Neurosci. 1995;15(1 pt 1):333-341.

26. Meyer RA, Davis KD, Cohen RH, Treede RD, Campbell JN. Mechanically insensitive afferents (MIAs) in cutaneous nerves of monkey. Brain Res. 1991;561(2):252-261.

27. Cain DM, Khasabov SG, Simone DA. Response properties of mechanoreceptors and nociceptors in mouse glabrous skin: an in vivo study. J Neurophysiol. 2001;85(4):1561-1574.

28. Darian-Smith I, Johnson KO, Dykes R. "Cold" fiber population innervating palmar and digital skin of the monkey: responses to cooling pulses. J Neurophysiol. 1973;36(2):325-346

29. Koltzenburg M, Stucky CL, Lewin GR. Receptive properties of mouse sensory neurons innervating hairy skin. J Neurophysiol. 1997;78(4):1841-1850.

30. Zylka MJ, Rice FL, Anderson DJ. Topographically distinct epidermal nociceptive circuits revealed by axonal tracers targeted to mrgprd. Neuron. 2005;45(1):17-25.

31. Lumpkin EA, Caterina MJ. Mechanisms of sensory transduction in the skin. Nature. 2007 445(7130):858-865

32. Amir R, Devor M. Electrical excitability of the soma of sensory neurons is required for spike invasion of the soma, but not for through-conduction. BiophysJ. 2003;84(4):2181-2191.

33. Woolf CJ, Costigan M. Transcriptional and posttranslational plasticity and the generation of inflammatory pain. Proc Natl Acad Sci U S A. 1999 96(14):7723-7730.

34. Cheng J-K, Ji R-, R. Intracellular signaling in primary sensory neurons and persistent pain. Neurochem Res. 2008;33(10):1970-1978.

35. Huang L-YM, Neher E. Ca2+-dependent exocytosis in the somata of dorsal root ganglion neurons. Neuron. 1996;17(1):135-145.

36. Schmidt M, Dubin AE, Petrus MJ, Earley TJ, Patapoutian A. Nociceptive signals induce trafficking of TRPA 1 to the plasma membrane. Neuron. 2009; 64(4):498-509.

37. Alvarez-Leefmans FJ. Chloride transporters in presynaptic inhibition, pain and neurogenic inflammation. In: Alvarez-Leefmans FJ, Delpire E, eds. Physiology and Pathology of Chloride Transporters and Channels in the Nervous System. New York, New York, USA: Academic Press; 2009:439-470.

38. Millan MJ. The induction of pain: an integrative review. Prog Neurobiol. 1999;57(1):1-164.

39. Heinricher MM, Tavares I, Leith JL, Lumb BM. Descending control of nociception: Specificity, recruitment and plasticity. Brain Res Rev. 2009; 60(1):214-225.

40. Cummins TR, Rush AM, Estacion M, Dib-Hajj SD, Waxman SG. Voltage-clamp and current-clamp recordings from mammalian DRG neurons. Nat Protoc. 2009;4(8):1103-1112.

41. Malin SA, Davis BM, Molliver DC. Production of dissociated sensory neuron cultures and considerations for their use in studying neuronal function and plasticity. Nat Protoc. 2007;2(1):152-160.
42. Caterina MJ, et al. Impaired nociception and pain sensation in mice lacking the capsaicin receptor. Science. 2000;288(5464):306-313.

43. Davis JB, et al. Vanilloid receptor-1 is essential for inflammatory thermal hyperalgesia. Nature. 2000; 405(6783):183-187.

44. Zimmermann K, Leffler A, Fischer MM, Messlinger K, Nau C, Reeh PW. The TRPV1/2/3 activator 2-aminoethoxydiphenyl borate sensitizes native nociceptive neurons to heat in wildtype but not TRPV1 deficient mice. Neuroscience. 2005;135(4):1277-1284.

45. St Pierre M, Reeh PW, Zimmermann K. Differentia effects of TRPV channel block on polymodal activation of rat cutaneous nociceptors in vitro. Exp Brain Res. 2009;196(1):31-44.

46. Petruska JC, Napaporn J, Johnson RD, Cooper BY. Chemical responsiveness and histochemical phenotype of electrophysiologically classified cells of the adult rat dorsal root ganglion. Neurosience. 2002;115(1):15-30.

47. Hjerling-Leffler J, Alqatari M, Ernfors P, Koltzenburg M. Emergence of functional sensory subtypes as defined by transient receptor potential channel expression. J Neurosci. 2007;27(10):2435-2443.

48. Lawson SN. Phenotype and function of somatic primary afferent nociceptive neurones with CAdelta- or Aalpha/beta-fibres. Exp Physiol. 2002; 87(2):239-244

49. Woodbury CJ, et al. Nociceptors lacking TRPV1 and TRPV2 have normal heat responses. J Neurosci. 2004:24(28):6410-6415.

50. Lawson JJ, McIlwrath SL, Woodbury CJ, Davis BM, Koerber HR. TRPV1 unlike TRPV2 is restricted to a subset of mechanically insensitive cutaneous nociceptors responding to heat. J Pain. 2008;9(4):298-308.

51. Bogen O, Dreger M, Gillen C, Schröder W, Hucho F. Identification of versican as an isolectin B4binding glycoprotein from mammalian spinal cord tissue. FEBS J. 2005;272(5):1090-1102.

52. Price TJ, Flores CM. Critical evaluation of the colocalization between calcitonin gene-related peptide, substance $P$, transient receptor potential vanilloid subfamily type 1 immunoreactivities and isolectin B4 binding in primary afferent neurons of the rat and mouse. J Pain. 2007;8(3):263-272.

53. Carr RW, Pianova S, McKemy DD, Brock JA. Action potential initiation in the peripheral terminals of cold-sensitive neurones innervating the guinea-pig cornea. J Physiol. 2009;587(pt 6):1249-1264.

54. Hille B. Ion Channels of Excitable Membranes. 3rd ed. Sunderland, Massachusetts, USA: Sinauer Associates, Inc.; 2001

55. Treede RD, Meyer RA, Raja SN, Campbell JN. Evidence for two different heat transduction mechanisms in nociceptive primary afferents innervating monkey skin. J Physiol. 1995;483(pt 3):747-758.

56. Campbell JN, LaMotte RH. Latency to detection of first pain. Brain Res. 1983;266(2):203-208.

57. Ringkamp M, Peng YB, Wu G, Hartke TV, Campbell JN, Meyer RA. Capsaicin responses in heatsensitive and heat-insensitive A-fiber nociceptors. J Neurosci. 2001;21(12):4460-4468.

58. Caterina MJ, Schumacher MA, Tominaga M, Rosen TA, Levine JD, Julius D. The capsaicin receptor: a heat-activated ion channel in the pain pathway. Nature. 1997;389(6653):816-824.

59. Treede R-D, Meyer RA, Campbell JN. Myelinated mechanically insensitive afferents from monkey hairy skin: heat-response properties. J Neurophysiol. 
1998;80(3):1082-1093.

60. Schmelz M, Schmid R, Handwerker HO, Torebjörk HE. Encoding of burning pain from capsaicintreated human skin in two categories of unmyelinated nerve fibres. Brain. 2000;123(pt 3):560-571.

61. Wood JN, Winter J, James IF, Rang HP, Yeats J, Bevan S. Capsaicin-induced ion fluxes in dorsal root ganglion cells in culture. J Neurosci. 1988;8(9):3208-3220.

62. Caterina MJ, Rosen TA, Tominaga M, Brake AJ, Julius D. A capsaicin-receptor homologue with a high threshold for noxious heat. Nature. 1999;398(6726):436-441.

63. Alloui A, et al. TREK-1, a K(+) channel involved in polymodal pain perception. EMBO J. 2006; 25(11):2368-2376.

64. Mandadi S, et al. TRPV3 in keratinocytes transmits temperature information to sensory neurons via ATP. Pflugers Arch. 2009;458(6):1093-1102.

65. Foulkes T, WoodJ.Mechanisms of cold pain. Channels. 2007;1(3):154-160

66. Davis KD, Pope GE. Noxious cold evokes multiple sensations with distinct time courses. Pain. 2002;98(1-2):179-185.

67. Schepersm RJ, Ringkamp M. Thermoreceptors and thermosensitive afferents. NeurosciBiobehav Rev. 2010; 34(2):177-184.

68. Allchorne A, Broom D, Woolf C. Detection of cold pain, cold allodynia and cold hyperalgesia in freely behaving rats. Mol Pain. 2005;1:36.

69. Bautista DM, et al. The menthol receptor TRPM8 is the principal detector of environmental cold. Nature. 2007;448(7150):204-208.

70. Babes A, Zorzon D, Reid G. Two populations of cold-sensitive neurons in rat dorsal root ganglia and their modulation by nerve growth factor. EurJ Neurosci. 2004;20(9):2276-2282.

71. Thut PD, Wrigley D, Gold MS. Cold transduction in rat trigeminal ganglia neurons in vitro. Neuroscience. 2003;119(4):1071.

72. Babes A. Ion channels involved in cold detection in mammals: TRP and non-TRP mechanisms. Biophysical Rev. 2009;1(4):193-200.

73. Colburn RW, et al. Attenuated cold sensitivity in TRPM8 null mice. Neuron. 2007;54(3):379-386.

74. Dhaka A, Murray AN, Mathur J, Earley TJ, Petrus MJ, Patapoutian A. TRPM8 is required for cold sensation in mice. Neuron. 2007;54(3):371-378.

75. Gentry C, Stoakley N, Andersson DA, Bevan S. The roles of IPLA2, TRPM8 and TRPA1 in chemically induced cold hypersensitivity. Mol Pain. 2010;6:4.

76. Dhaka A, Earley TJ, Watson J, Patapoutian A. Visualizing cold spots: TRPM8-expressing sensory neurons and their projections. J Neurosci. 2008; 28(3):566-575.

77. Takashima Y, Daniels RL, Knowlton W, Teng J Liman ER, McKemy DD. Diversity in the neural circuitry of cold sensing revealed by genetic axonal labeling of transient receptor potential melastatin 8 neurons. J Neurosci. 2007;27(51):14147-14157.

78. Magerl W, Fuchs PN, Meyer RA, Treede RD. Roles of capsaicin-insensitive nociceptors in cutaneous pain and secondary hyperalgesia. Brain. 2001; 124(pt 9):1754-1764

79. Viana F. Understanding the mechanisms of coldevoked pain in humans. Pain. 2009;147(1-3):7-8.

80. Reid G, Flonta M-L. Cold transduction by inhibition of a background potassium conductance in rat primary sensory neurones. Neurosci Lett. 2001; 297(3):171-174.

81. Kwan KY, et al. TRPA1 contributes to cold, mechanical, and chemical nociception but is not essential for hair-cell transduction. Neuron. 2006 50(2):277-289.

82. Karashima Y, et al. TRPA1 acts as a cold sensor in vitro and in vivo. Proc Natl Acad Sci U S A. 2009; 106(4):1273-1278

83. Sawada Y, Hosokawa H, Hori A, Matsumura K,
Kobayashi S. Cold sensitivity of recombinant TRPA1 channels. Brain Res. 2007;1160:39-46.

84. Jordt S-E, et al. Mustard oils and cannabinoids excite sensory nerve fibres through the TRP channel ANKTM1. Nature. 2004;427(6971):260-265.

85. Bautista DM, Jordt S-E, Nikai T, et al. TRPA1 mediates the inflammatory actions of environmental irritants and proalgesic agents. Cell. 2006; 124(6):1269-1282.

86. Bandell M, et al. Noxious cold ion channel TRPA1 is activated by pungent compounds and bradykinin. Neuron. 2004;41(6):849-857.

87. Dai Y, et al. Sensitization of TRPA1 by PAR2 contributes to the sensation of inflammatory pain. J Clin Invest. 2007;117(7):1979-1987.

88. Hinman A, Chuang HH, Bautista DM, Julius D. TRP channel activation by reversible covalent modification. Proc Natl Acad Sci U S A. 2006; 103(51):19564-19568.

89. Macpherson LJ, et al. Noxious compounds activate TRPA1 ion channels through covalent modification of cysteines. Nature. 2007;445(7127):541-545.

90. Bang S, Hwang SW. Polymodal ligand sensitivity of TRPA1 and its modes of interactions. J Gen Physiol. 2009;133(3):257-262.

91. Hu J, Milenkovic N, Lewin GR. The high threshold mechanotransducer: A status report. Pain. 2006; 120(1-2):3-7

92. Chalfie M. Neurosensory mechanotransduction. Nat Rev Mol Cell Biol. 2009;10(1):44-52.

93. Garcia-Anoveros J, Corey DP. The molecules of mechanosensation. Annu Rev Neurosci. 1997;20:567-594.

94. Wetzel C, et al. A stomatin-domain protein essential for touch sensation in the mouse. Nature. 2007; 445(7124):206-209

95. Nassar MA, et al. Nociceptor-specific gene deletion reveals a major role for Nav1.7 (PN1) in acute and inflammatory pain. Proc Natl Acad Sci U S A. 2004; 101(34):12706-12711.

96. McCarter GC, Reichling DB, Levine JD. Mechanical transduction by rat dorsal root ganglion neurons in vitro. Neurosci Lett. 1999;273(3):179-182.

97. Bhattacharya MR, Bautista DM, Wu K, Haeberle $\mathrm{H}$, Lumpkin EA, Julius D. Radial stretch reveals distinct populations of mechanosensitive mammalian somatosensory neurons. Proc Natl Acad Sci US A. 2008;105(50):20015-20020

98. Alessandri-Haber $\mathrm{N}$, et al. Hypotonicity induces TRPV4-mediated nociception in rat. Neuron. 2003;39(3):497-511.

99. Schulz DJ, Temporal S, Barry DM, Garcia ML. Mechanisms of voltage-gated ion channel regulation: from gene expression to localization. Cell Mol Life Sci. 2008;65(14):2215-2231.

100.Zimmermann $\mathrm{K}$, et al. Sensory neuron sodium channel Nav1.8 is essential for pain at low temperatures. Nature. 2007;447(7146):855-858.

101.Akopian AN, et al. The tetrodotoxin-resistant sodium channel SNS has a specialized function in pain pathways. Nat Neurosci. 1999;2(6):541-548.

102.Rush AM, Cummins TR, Waxman SG. Multiple sodium channels and their roles in electrogenesis within dorsal root ganglion neurons. J Physiol. 2007;579(pt 1):1-14.

103. Nassar MA, Levato A, Stirling LC, Wood JN. Neuropathic pain develops normally in mice lacking both Nav1.7 and Nav1.8. Mol Pain. 2005;1:24.

104. Cox JJ, et al. An SCN9A channelopathy causes congenital inability to experience pain. Nature. 2006; 444(7121):894-898.

105.Latremoliere A, Woolf CJ. Central sensitization: a generator of pain hypersensitivity by central neural plasticity. J Pain. 2009;10(9):895-926.

106. Campbell JN, Meyer RA. Sensitization of unmyelinated nociceptive afferents in monkey varies with skin type. J Neurophysiol. 1983;49(1):98-110.

107. Sandkuhler J. Models and mechanisms of hyperalgesia and allodynia. Physiol Rev. 2009;89(2):707-758.
108. Koltzenburg M, Lundberg LER, Torebjörk HE. Dynamic and static components of mechanical hyperalgesia in human hairy skin. Pain. 1992; 51(2):207-219.

109. Bharali LAM, Lisney SJW. The relationship between unmyelinated afferent type and neurogenic plasma extravasation in normal and reinnervated rat skin. Neuroscience. 1992;47(3):703-712.

110.Lin Q, Li D, Xu X, Zou X, Fang L. Roles of TRPV1 and neuropeptidergic receptors in dorsal root reflex-mediated neurogenic inflammation induced by intradermal injection of capsaicin. Mol Pain. 2007;3:30.

111.Richardson JD, Vasko MR. Cellular mechanisms of neurogenic inflammation.JPharmacol Exp Ther. 2002; 302(3):839-845.

112.Mizumura K, Sugiura T, Katanosaka K, Banik RK, Kozaki Y. Excitation and sensitization of nociceptors by bradykinin: what do we know? Exp Brain Res. 2009;196(1):53-65.

113.Leffler A, Monter B, Koltzenburg M. The role of the capsaicin receptor TRPV1 and acid-sensing ion channels (ASICS) in proton sensitivity of subpopulations of primary nociceptive neurons in rats and mice. Neuroscience. 2006;139(2):699-709.

114. Reichling DB, Levine JD. Critical role of nociceptor plasticity in chronic pain. Trends Neurosci. 2009; 32(12):611-618.

115. Macpherson LJ, et al. An ion channel essential for sensing chemical damage. J Neurosci. 2007; 27(42):11412-11415

116. McNamara CR, et al. TRPA1 mediates formalin-induced pain. Proc Natl Acad Sci U S A. 2007; 104(33):13525-13530.

117. Defrin R, Ohry A, Blumen N, Urca G. Sensory determinants of thermal pain. Brain. 2002;125(pt 3):501-510.

118. Belmonte C, Viana F. Molecular and cellular limits to somatosensory specificity. Mol Pain. 2008;4:14.

119. Nagy JI, van der Kooy D. Effects of neonatal capsaicin treatment on nociceptive thresholds in the rat. J Neurosci. 1983;3(6):1145-1150.

120.Abrahamsen B, et al. The cell and molecular basis of mechanical, cold, and inflammatory pain. Science. 2008;321(5889):702-705.

121. Rau KK, et al. Mrgprd enhances excitability in specific populations of cutaneous murine polymodal nociceptors. J Neurosci. 2009;29(26):8612-8619.

122. Cavanaugh DJ, et al. Distinct subsets of unmyelinated primary sensory fibers mediate behavioral responses to noxious thermal and mechanical stimuli. Proc Natl Acad Sci U S A. 2009;106(22):9075-9080.

123. Torebjork HE, LaMotte RH, Robinson CJ. Peripheral neural correlates of magnitude of cutaneous pain and hyperalgesia: simultaneous recordings in humans of sensory judgments of pain and evoked responses in nociceptors with C-fibers. JNeurophysiol. 1984;51(2):325-339.

124. Weidner C, Schmelz M, Schmidt R, Hansson B, Handwerker HO, Torebjörk HE. Functional attributes discriminating mechano-insensitive and mechano-responsive $\mathrm{C}$ nociceptors in human skin. J Neurosci. 1999;19(22):10184-10190.

125. Koltzenburg M, Handwerker HO. Differential ability of human cutaneous nociceptors to signal mechanical pain and to produce vasodilatation. J Neurosci. 1994;14(3 pt 2):1756-1765.

126. Schmidt R, Schmelz M, Torebjörk HE, Handwerker HO. Mechano-insensitive nociceptors encode pain evoked by tonic pressure to human skin. Neuroscience. 2000;98(4):793-800.

127. Koppert W, Brueckl V, Weidner C, Schmelz M. Mechanically induced axon reflex and hyperalgesia in human UV-B burn are reduced by systemic lidocaine. Eur J Pain. 2004;8(3):237-244.

128. Lynn B, Schütterle S, Pierau FK. The vasodilator component of neurogenic inflammation is caused by a special subclass of heat-sensitive nociceptors in the skin of the pig. J Physiol. 1996;494(pt 2):587-593. 
129. Obreja O, et al. Patterns of activity-dependent conduction velocity changes differentiate classes of unmyelinated mechano-insensitive afferents including cold nociceptors, in pig and in human. Pain. 2010;148(1):59-69.

130.Schmelz M, Michael K, Weidner C, Schmidt R, Torebjörk HE, Handwerker HO. Which nerve fibers mediate the axon reflex flare in human skin? Neuroreport. 2000;11(3):645-648.

131.Baumann TK, Simone DA, Shain CN, LaMotte RH. Neurogenic hyperalgesia: the search for the primary cutaneous afferent fibers that contribute to capsaicin-induced pain and hyperalgesia. J Newrophysiol. 1991;66(1):212-227.

132.Ziegler EA, Magerl W, Meyer RA, Treede RD. Secondary hyperalgesia to punctate mechanical stimuli: Central sensitization to A-fibre nociceptor input. Brain. 1999;122(pt 12):2245-2257.

133. Meyer RA, Campbell JN. Evidence for two distinct classes of unmyelinated nociceptive afferents in monkey. Brain Res. 1981;224(1):149-152.

134.Bölcskei K, et al. Investigation of the role of TRPV1 receptors in acute and chronic nociceptive processes using gene-deficient mice. Pain. 2005; 117(3):368-376.

135. Peier AM, et al. A heat-sensitive TRP channel expressed in keratinocytes. Science. 2002;296(5575):2046-2049.

136.Xu H, et al. TRPV3 is a calcium-permeable tem- perature-sensitive cation channel. Nature. 2002; 418(6894):181-186.

137. Huang SM, et al. Overexpressed transient receptor potential vanilloid 3 ion channels in skin keratinocytes modulate pain sensitivity via prostaglandin E2. J Neurosci. 2008;28(51):13727-13737.

138. Moqrich A, et al. Impaired thermosensation in mice lacking TRPV3, a heat and camphor sensor in the skin. Science. 2005;307(5714):1468-1472.

139. Lee H, Iida T, Mizuno A, Suzuki M, Caterina MJ. Altered thermal selection behavior in mice lacking transient receptor potential vanilloid 4. J Neurosci. 2005;25(5):1304-1310

140.Todaka H, Taniguchi J, Satoh J, Mizuno A, Suzuki M. Warm temperature-sensitive transient receptor potential vanilloid 4 (TRPV4) plays an essential role in thermal hyperalgesia. J Biol Chem. 2004 279(34):35133-35138.

141.Alessandri-Haber N, Dina OA, Joseph EK, Reichling D, Levine JD. A transient receptor potential vanilloid 4-dependent mechanism of hyperalgesia is engaged by concerted action of inflammatory mediators. J Neurosci. 2006;26(14):3864-3874.

142.Suzuki M, Mizuno A, Kodaira K, Imai M. Impaired pressure sensation in mice lacking TRPV4. J Biol Chem. 2003;278(25):22664-22668.

143. Cohen A, Sagron R, Somech E, Segal-Hayouna Y, Zilberberg N. Pain-associated signals, acidosis and lyso- phosphatidic acid, modulate the neuronal K2P2.1 channel. Mol Cell Neurosci. 2009;40(3):382-389.

144. Noel J, et al. The mechano-activated $\mathrm{K}+$ channels TRAAK and TREK- 1 control both warm and cold perception. EMBOJ. 2009;28(9):1308-1318.

145Proudfoot CJ, et al. Analgesia mediated by the TRPM8 cold receptor in chronic neuropathic pain. Curr Biol. 2006;16(16):1591-1605.

146.Obata $\mathrm{K}$, et al. TRPA1 induced in sensory neurons contributes to cold hyperalgesia after inflammation and nerve injury. J Clin Invest. 2005;115(9):2393-2401.

147Petrus $\mathrm{M}$, et al. A role of TRPA1 in mechanical hyperalgesia is revealed by pharmacological inhibition. Mol Pain. 2007;3:40.

148Kwan KY, Glazer JM, Corey DP, Rice FL, Stucky CL. TRPA1 modulates mechanotransduction in cutaneous sensory neurons. J Neurosci. 2009; 29(15):4808-4819.

149Alessandri-Haber N, Joseph E, Dina OA, Liedtke W, Levine JD. TRPV4 mediates pain-related behavior induced by mild hypertonic stimuli in the presence of inflammatory mediator. Pain. 2005; 118(1-2):70-79.

150Chien LY, Cheng JK, Chu D, Cheng CF, Tsaur ML. Reduced expression of A-type potassium channels in primary sensory neurons induces mechanical hypersensitivity. J Neurosci. 2007; 27(37):9855-9865. 